\title{
The Current Status, Potential Benefits and Future Prospects of the Australian Biogas Sector
}

\author{
Tien Ngo, Andrew S. Ball, Esmaeil Shahsavari \\ School of Science, RMIT University, Melbourne, Australia \\ Email: s3501132@student.rmit.edu.au
}

How to cite this paper: Ngo, T., Ball, A.S. and Shahsavari, E. (2021) The Current Status, Potential Benefits and Future Prospects of the Australian Biogas Sector. Journal of Sustainable Bioenergy Systems, 11, 14-32.

https://doi.org/10.4236/jsbs.2021.111002

Received: November 10, 2020

Accepted: March 5, 2021

Published: March 8, 2021

Copyright $\odot 2021$ by author(s) and Scientific Research Publishing Inc. This work is licensed under the Creative Commons Attribution International License (CC BY 4.0).

http://creativecommons.org/licenses/by/4.0/

(c) (i) Open Access

\begin{abstract}
Anaerobic digestion technology provides a new approach to treat organic waste while generating greenhouse gas (GHG) savings. Moreover, the methane gas produced during the process can be used to generate electricity. In order to ensure that Australia stays on its trajectory towards a carbon neutral future, the use of anaerobic digestion technology to treat its abundant organic waste streams should be considered. Thirty million tonnes (Mt) of organic waste was produced in 2017. The use of anaerobic digestion to treat 1 tonne of waste could result in 0.143 tonne of $\mathrm{CO}_{2}$-e in GHG savings. In contrast, other more widely employed waste disposal methods such as landfilling, composting and incineration may generate GHG emissions. Additionally, the use of methane for electricity production also generates the least GHG emissions per MWh. This is approximately 3 times lower than crude oil, 4 times lower than black coal and 5 times lower than brown coal. However, the adoption and implementation of anaerobic digestion technology in Australia face several immediate constraints. Firstly, anaerobic digestion technology is deemed unprofitable, incurring high initial capital cost, operating costs and extremely long payback periods. Secondly, there is a lack of government support in terms of a national target for biogas production via anaerobic digestion. This review will provide an in-depth analysis into the current state of the Australian biogas sector. In addition, the review discusses the opportunities to make anaerobic digestion technology more financially viable and to accelerate the growth of the Australian biogas sector.
\end{abstract}

\section{Keywords}

Anaerobic Digestion, Biogas Sector, Biogas, Methane, Renewable Energy, GHG Emission, GHG Saving 


\section{The different organic waste streams in Australia}

\subsection{Introduction}

In the financial year 2017, Australia generated 67 million tonnes (Mt) of waste [1]. Of this, an estimated $30 \mathrm{Mt}$ was organic in nature [1]. The percentage composition of all the different types of organic waste is shown in Figure 1.

\subsection{Livestock Manure}

Livestock manure is a protein-rich substrate. In Australia, livestock manure represented 34\% of all the organic waste generated in 2017. Livestock manure is an abundant continuous feedstock. In 2019, Australia had a total of 22 million cows (raised for meat), 2 million dairy cows, 66 million lamb and sheep, 2 million pigs and a poultry flock of 137 million [2].

\subsection{Bagasse and Wheat Straw}

Bagasse is the dry pulpy fibrous residue produced when sugarcane is crushed during the extraction of their juice. Together with grape bagasse, this residue is one of the most abundant lignocellulosic biomass produced in Australia, accounting for $20 \%$ of all organic waste generated in Australia in 2017 (Figure 1). Wheat straw is an abundant agricultural by-product comprising dry stalks from wheat production, typically making up half the total yield of wheat; wheat straw is a lignocellulosic biomass containing cellulose, hemicellulose and lignin. In 2019, Australia produced 15.2 million tonnes (Mt) of wheat [3].

\subsection{Winery Waste}

Australia is one of the leading grape-producing countries in the world; the Australian wine grape crush in 2019 was 1.73 Mt with a long-term average of $1.75 \mathrm{Mt}$ [4] [5]. Wineries have long been regarded as a major source of pollution due to the amount of organic waste generated from the winemaking

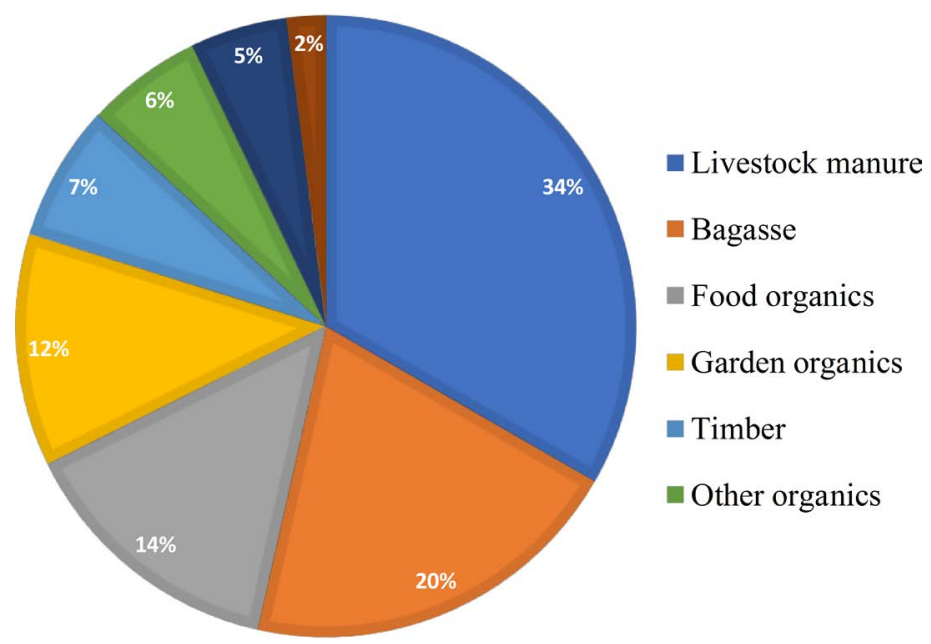

Figure 1. The percentage composition of the different types of organic waste in Australia in the year 2016 to 2017 [1]. 
Table 1. The different winery wastes and their percentage composition, origin, current treatment and current application. Adapted from Ahmad, Yadav [4].

\begin{tabular}{|c|c|c|c|}
\hline Type of winery waste & Percentage composition & Origin & Treatment/Application \\
\hline Grape leaves & NA & Harvesting & Landfilling, incineration \\
\hline Grape seeds & $3 \%-6 \%$ of total volume & Wet-pomace from the wine-making process & $\begin{array}{l}\text { Nutraceutical properties, extraction of } \\
\text { anti-cancerous compounds, natural } \\
\text { anti-oxidants }\end{array}$ \\
\hline Grape pomace & $\begin{array}{l}15 \% \text { of total dry matter or } \\
25 \%-45 \% \text { of wet matter }\end{array}$ & $\begin{array}{l}\text { Solid residue obtained from juicing and } \\
\text { wine-making }\end{array}$ & $\begin{array}{l}\text { Food ingredients, chemicals, anaerobic } \\
\text { digestion }\end{array}$ \\
\hline Wine lees & $3.5 \%-8.5 \%$ of total volume & $\begin{array}{l}\text { Clarification, post-fermentation, as a residue } \\
\text { after filtration and centrifugation }\end{array}$ & Disposed along with wastewater \\
\hline
\end{tabular}

process [4]. The different types of waste, their percentage composition, their origins and their current treatments or applications, are outlined in Table 1.

\subsection{Food Waste}

Food waste accounts for 14\% of all organic waste generated in Australia in 2017. Food waste comprises of readily degradable carbohydrates, proteins and lipids. However, the varying compositions and chemical properties of food waste make it a challenging substrate for reuse. As a result, most food wastes in Australia are sent to landfill for disposal. Excluding hazardous food waste, $4.3 \mathrm{Mt}$ of food waste or $87 \%$ of total food waste generated was disposed to landfill in 2017 [1]. In contrast, only $1 \%$ of the total food waste was utilised to generate renewable energy [1].

\section{Fate of Organic Waste in Australia}

Organic waste can undergo a variety of waste disposal treatments in Australia. Such treatments include landfilling, incineration, composting and anaerobic digestion. Each treatment carries its own advantages and disadvantages, these are summarised in Table 2.

\subsection{Landfills}

A significant amount $(6.7 \mathrm{Mt})$ of this organic waste was deposited in the landfill in 2017. Landfilling remains one of the most widely employed waste disposal methods and can be defined as the disposal of large quantities of waste onto a land space [6] (Table 2). However, landfilling carries many immediate concerns such as increasing limited availability of space, environmental pollution via landfill gas production, groundwater contamination by leachate and negative impacts on human health [6] [7] (Table 2). Landfills can continue to be active 
for 100 years, emitting large quantities of greenhouse gas (GHGs) including methane, carbon dioxide and nitrous oxides into the atmosphere long after closure due to the continuous biodegradation of organics [7] (Table 2). Typically, 1 tonne of waste emits $350 \mathrm{~kg} \mathrm{CO}_{2}$-e [8]. Landfill gas is composed of $50 \%-55 \%$ methane, $45 \%-50 \% \mathrm{CO}_{2}$ and $2 \%-5 \%$ of other non-methanic compounds and inorganic compounds [9].

Methane is an extremely potent greenhouse gas (GHG); it is 36 times more effective than $\mathrm{CO}_{2}$ in trapping atmospheric heat. A total of $8.4 \mathrm{Mt}$ of $\mathrm{CO}_{2}$ equivalent $\left(\mathrm{CO}_{2}-\mathrm{e}\right)$ was emitted from all Australian landfills into the atmosphere in 2015 [10]. However, given proper landfill gas (LFG) collection and treatment, LFG can be used to generate electricity or heat; the LFG emitted from $1 \mathrm{Mt}$ of waste can generate $0.78 \mathrm{MW}$ of electricity [9]. In Australia, modern landfills are equipped with appropriate capture and combustion systems to prevent the emissions of LFG into the atmosphere; pipes are installed in landfills to collect and channel LFG to a combustion device. However, the main purpose of combusting LFG in Australia is to reduce the emission of $\mathrm{CH}_{4}$ into the atmosphere; $\mathrm{CH}_{4}$ components are converted into less harmful $\mathrm{CO}_{2}$ during combustion and emitted. This was further reflected in the study by Emission Assurance Reduction Committee [10], which reported that the total generated $\mathrm{CO}_{2}$-e of $16.5 \mathrm{Mt}$ was reduced to a net emission of only $8.4 \mathrm{Mt} \mathrm{CO}_{2}$-e in 2015.

\subsection{Incineration}

Incineration of organic waste is another method of management. Incineration can be defined as the combustion of waste with low moisture content and high calorific values using a furnace with temperatures ranging from $750^{\circ} \mathrm{C}$ to $1100^{\circ} \mathrm{C}$ [6]. Incineration can reduce waste mass and volume by up to $75 \%$ and $90 \%$ respectively and also incorporates heat and electricity production; it is generally preferred over landfilling [6] (Table 2). While the incineration of waste carries the potential for energy generation, it requires low moisture content for efficient thermochemical conversion [6] [7]. Therefore, only a small portion of all organic waste may be suitable for direct heat and power generation [7] (Table 2). As data for waste incineration is unavailable in Australia, data from the U.S. will be used for comparison. In 2018, 29.5 Mt of waste was incinerated in the U.S. to yield 14 billion KW of electricity; $1 \mathrm{Mt}$ of waste incinerated can yield $48 \mathrm{KW}$ of electricity [11]. However, incineration can potentially generate significant GHG emissions; for 1 tonne of waste incinerated $1381.4 \mathrm{~kg}$ of $\mathrm{CO}_{2}, 14.9 \mathrm{~kg} \mathrm{CO}_{2}$-e of $\mathrm{N}_{2} \mathrm{O}$ and $0.15 \mathrm{~kg} \mathrm{CO}_{2}$-e of $\mathrm{CH}_{4}$ can be produced [12].

\subsection{Composting}

Organic waste can also be managed via composting. Composting can be defined as the aerobic degradation of organic matter to produce $\mathrm{CO}_{2}$ and limit the emission of $\mathrm{CH}_{4}$ [7]. Composting is simple to operate and has the capability to stabilise organic waste. Although it does not result in energy production, 
composting can produce a valuable product; compost possesses high agricultural values [7] (Table 2). Composting can be carried out at different scales, either in centralised facilities or in homes [7]. However, the potential for large quantities of methane to be produced and emitted in poorly aerated conditions during composting remains a challenge, especially in home composting systems [7] (Table 2). Composting can release up to $100 \mathrm{~kg} \mathrm{CO}_{2}$-e of $\mathrm{CH}_{4}$ and 71.52 $\mathrm{kg} \mathrm{CO}_{2}$-e of $\mathrm{N}_{2} \mathrm{O}$ per tonne of waste [12]. Composting may also become inappropriate in densely populated urban areas due to hygienic concerns and the need for constant monitoring to prevent the emission of GHG [7] (Table 2).

\subsection{Anaerobic Digestion}

Organic waste can be utilised in anaerobic digestion (AD) to generate electricity and produce other useful digestate products [1]. Anaerobic digestion refers to the natural biodegradation of organic matter with the aid of microorganisms in anoxic conditions [13]. Some examples of these microorganisms are Bacillus, Acetivibrio, Clostridia and Methanobacterium (Figure 2). Unlike landfills where anaerobic digestion also occurs, the anaerobic digestion of organic waste typically occurs in anaerobic digestion plants using anaerobic digesters under strict conditions. Anaerobic digestion is also highly selective in terms of the type of

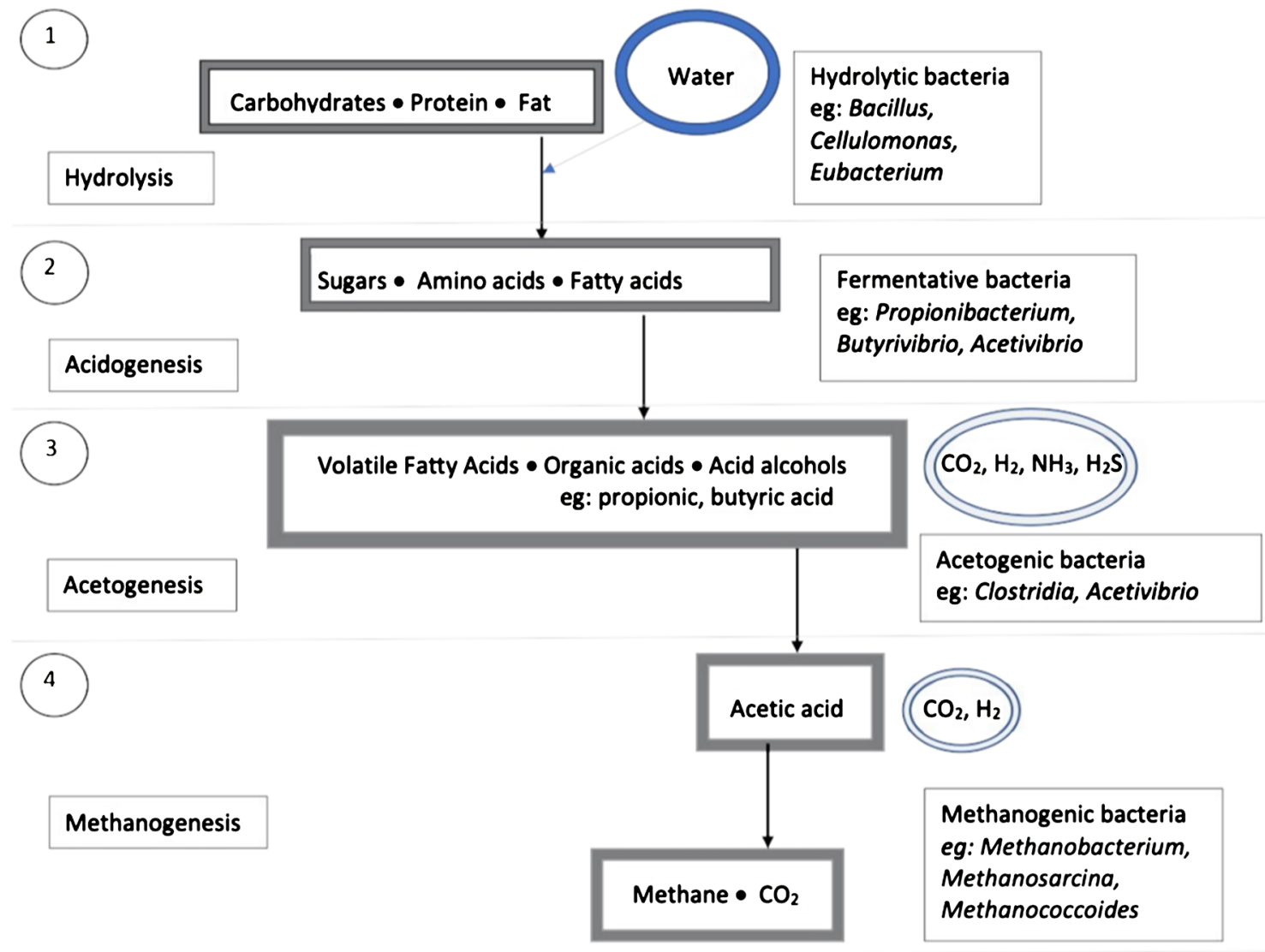

Figure 2. The 4 main stages of anaerobic digestion of organic waste together with examples of the microorganisms involved. 
feedstock being utilised, operating temperature and methods of pre-treatment.

The biological conversion of organic waste into biogas consists of 4 main stages: hydrolysis, acidogenesis, acetogenesis and methanogenesis (Figure 2) [15]. During hydrolysis, hydrolytic bacteria break down large and complex organic matter into monomers or oligomers such as amino acids, sugar, glycerol and long-chain fatty acids. (Figure 2) [14] [15]. Monomers are then converted into volatile fatty acids (VFA), organic acids and acid alcohols by fermentative bacteria in the second stage; ammonia and hydrogen sulfide are sometimes also released during the process (Figure 2) [15]. Thirdly, VFA is transformed into acetic acid, $\mathrm{CO}_{2}$ and $\mathrm{H}_{2}$ by acetogenic bacteria via anaerobic oxidation (Figure 2) [14] [15]. Acetate can also be produced from $\mathrm{H}_{2}$ and $\mathrm{CO}_{2}$ by homoacetogens, an $\mathrm{H}$-oxidising acetogenic bacteria [14]. In the last step, acetotrophic and hydrogenotrophic methanogens convert acetic acid and $\mathrm{H}_{2}$ into a mixture of $\mathrm{CO}_{2}$ and $\mathrm{CH}_{4}$ (Figure 2) [14] [15].

The main product of $\mathrm{AD}$ is biogas which, comprises up to $60 \% \mathrm{CH}_{4}, 40 \% \mathrm{CO}_{2}$ and a small mixture of other gases such as $\mathrm{NH}_{3}, \mathrm{~N}_{2} \mathrm{O}, \mathrm{H}_{2} \mathrm{~S}$; the volume of other gases produced are dependent on the nitrogen and sulfur content of the feedstock respectively [16] [17] [18]. In particular, the production of $\mathrm{CH}_{4}$ from organic waste as a result of $\mathrm{AD}$ is highly desirable; $\mathrm{CH}_{4}$ is a promising source of renewable energy [17]. Although $\mathrm{CH}_{4}$ has long been regarded as a harmful GHG, it can be utilised as an alternative source of energy supply given proper handling [17]. Methane carries the potential for various applications such as heating and electricity generation using fuel cells [14]. Methane can also be upgraded to be used as transportation fuel [14]. A study performed in 2010 on an AD plant in the Netherlands found that 1 tonne of organic waste treated by anaerobic digestion can yield 222.3 KWh of electricity [19]. The Jankadot Bioenergy plant in Australia has reported that it can potentially save 7138.6 tonnes of $\mathrm{CO}_{2}$-e from an annual volume of 50,000 tonnes of commercial and industrial biowaste via anaerobic digestion currently, this is the only available data of GHG savings from biogas plants. As such, it can be estimated that 1 tonne of organic waste treated by $\mathrm{AD}$ can save 0.143 tonne of $\mathrm{CO}_{2}$-e [20]. Gebrezgabher, Meuwissen [19] stated that the use of $\mathrm{AD}$ to treat organic waste produces no net carbon emissions.

From Table 2, it can be concluded that the use of $\mathrm{AD}$ to treat 1 tonne of waste generates GHG savings of 0.143 tonne of $\mathrm{CO}_{2}$-e (Table 2). In contrast, the use of landfill, incineration and composting all generate GHG emissions; $350 \mathrm{~kg} \mathrm{CO}_{2}-\mathrm{e}$, $1396.45 \mathrm{~kg}$ of $\mathrm{CO}_{2}$-e and $171.52 \mathrm{~kg} \mathrm{CO}_{2}$-e respectively. In addition, the use of 1 tonne of organic waste can produce $222.3 \mathrm{KWh}$ of electricity by $\mathrm{AD}$. This is significantly higher than using 1 tonne of organic waste to produce electricity via landfilling and incineration; $0.00078 \mathrm{KW}$ and $0.000047 \mathrm{KW}$ respectively. Unlike the other 3 waste treatment methods, composting does not generate electricity. Hence, $\mathrm{AD}$ represents a good alternative to treat waste in terms of GHG emissions and electricity production. 
Table 2. The different methods of organic waste disposal and their associated advantages and disadvantages.

\begin{tabular}{|c|c|c|c|c|c|}
\hline $\begin{array}{l}\text { Method of } \\
\text { organic waste } \\
\text { disposal }\end{array}$ & Advantages & Disadvantages & $\begin{array}{l}\text { GHG } \\
\text { production/ } \\
\text { tonne of waste }\end{array}$ & $\begin{array}{c}\text { Energy } \\
\text { production/ } \\
\text { tonne of waste }\end{array}$ & References \\
\hline Landfilling & $\begin{array}{l}\text { Disposal of a large } \\
\text { amount of waste at a } \\
\text { time }\end{array}$ & $\begin{array}{l}\text { Increasing limited availability of space } \\
\text { Environmental pollution via landfill gas } \\
\text { production } \\
\text { Groundwater contamination and negative } \\
\text { impacts on human health } \\
\text { Emission of large quantities of greenhouse } \\
\text { gas into the atmosphere after closure }\end{array}$ & $350 \mathrm{~kg} \mathrm{CO}_{2}-\mathrm{e}$ & $\begin{array}{l}0.00078 \mathrm{KW} \text { of } \\
\text { electricity }\end{array}$ & $\begin{array}{c}\text { Dastjerdi, Strezov [6], } \\
\text { EPA [9], } \\
\text { Lu, Qu [7], } \\
\text { Emission Assurance Reduction } \\
\text { Committee [10], } \\
\text { Sustainability Victoria [21] }\end{array}$ \\
\hline Incineration & $\begin{array}{l}\text { Reduction of waste } \\
\text { mass and volume by } \\
\text { up to } 75 \% \text { and } 90 \% \\
\text { Heat and electricity } \\
\text { production }\end{array}$ & $\begin{array}{l}\text { Suitability of waste for incineration } \\
\text { remains challenging }\end{array}$ & $\begin{array}{l}1396.45 \mathrm{~kg} \text { of } \\
\mathrm{CO}_{2}-\mathrm{e}\end{array}$ & $\begin{array}{l}0.000047 \mathrm{KW} \text { of } \\
\text { electricity }\end{array}$ & $\begin{array}{c}\text { EIA [11], } \\
\text { Kristanto and Koven [12], } \\
\text { Dastjerdi, Strezov [6], } \\
\text { Lu, Qu [7] }\end{array}$ \\
\hline Composting & $\begin{array}{l}\text { Simple to operate } \\
\text { Stabilisation of } \\
\text { organic waste } \\
\text { Production of } \\
\text { valuable compost } \\
\text { with high } \\
\text { agricultural value }\end{array}$ & $\begin{array}{l}\text { Potential for large quantities of methane } \\
\text { to be produced and emitted if poorly } \\
\text { conducted } \\
\text { Hygiene concerns in densely populated } \\
\text { areas } \\
\text { Constant monitoring }\end{array}$ & $\begin{array}{c}171.52 \mathrm{~kg} \\
\mathrm{CO}_{2}-\mathrm{e}\end{array}$ & NIL & $\begin{array}{c}\mathrm{Lu}, \mathrm{Qu}[7], \text { Kristanto and } \\
\text { Koven (2019) }\end{array}$ \\
\hline $\begin{array}{l}\text { Anaerobic } \\
\text { digestion }\end{array}$ & $\begin{array}{l}\text { Natural } \\
\text { biodegradation of } \\
\text { organic matter }\end{array}$ & $\begin{array}{l}\text { Strict requirements involved which may } \\
\text { incur high costs }\end{array}$ & $\begin{array}{c}\text { GHG } \\
\text { saving/tonne } \\
\text { of waste } \\
143 \mathrm{~kg} \text { of } \\
\mathrm{CO}_{2} \text {-e }\end{array}$ & $\begin{array}{l}222.3 \mathrm{KWh} \text { of } \\
\text { electricity }\end{array}$ & $\begin{array}{c}\text { Phong [18], } \\
\text { Carlu, Truong [20], } \\
\text { Gebrezgabher, Meuwissen [19] }\end{array}$ \\
\hline
\end{tabular}

\section{The Current State of Biogas Production in Australia}

Australia relies heavily on oil, coal, non-renewable natural gas and renewable energy for its energy consumption. The energy consumption by fuel type in Australia in the year 2017-2018, in petajoules, is summarised in Figure 3. Like all developed countries there is a heavy dependency on oil, followed by coal and non-renewable natural gas; $38.7 \%, 29.9 \%$ and $25.2 \%$ respectively. Renewable energy sources such as bioenergy only make up $6.2 \%$ of the statistic.

A number of government policies and facilities from the different states in Australia have already been put in place to further develop bioenergy technologies in Australia (Table 3).

From Table 3, only Queensland, NSW and Victoria have invested in large-scale technology and infrastructure to transform organic waste into bioenergy and subsequently, energy in the form of electricity. South Australia, Western Australia and Tasmania are still behind in terms of bioenergy production (Table 3). Queensland, Victoria and South Australia have introduced high levels of funding for the development of new bioenergy technology (Table 3). Queensland, NSW, Victoria and South Australia have made future plans to 


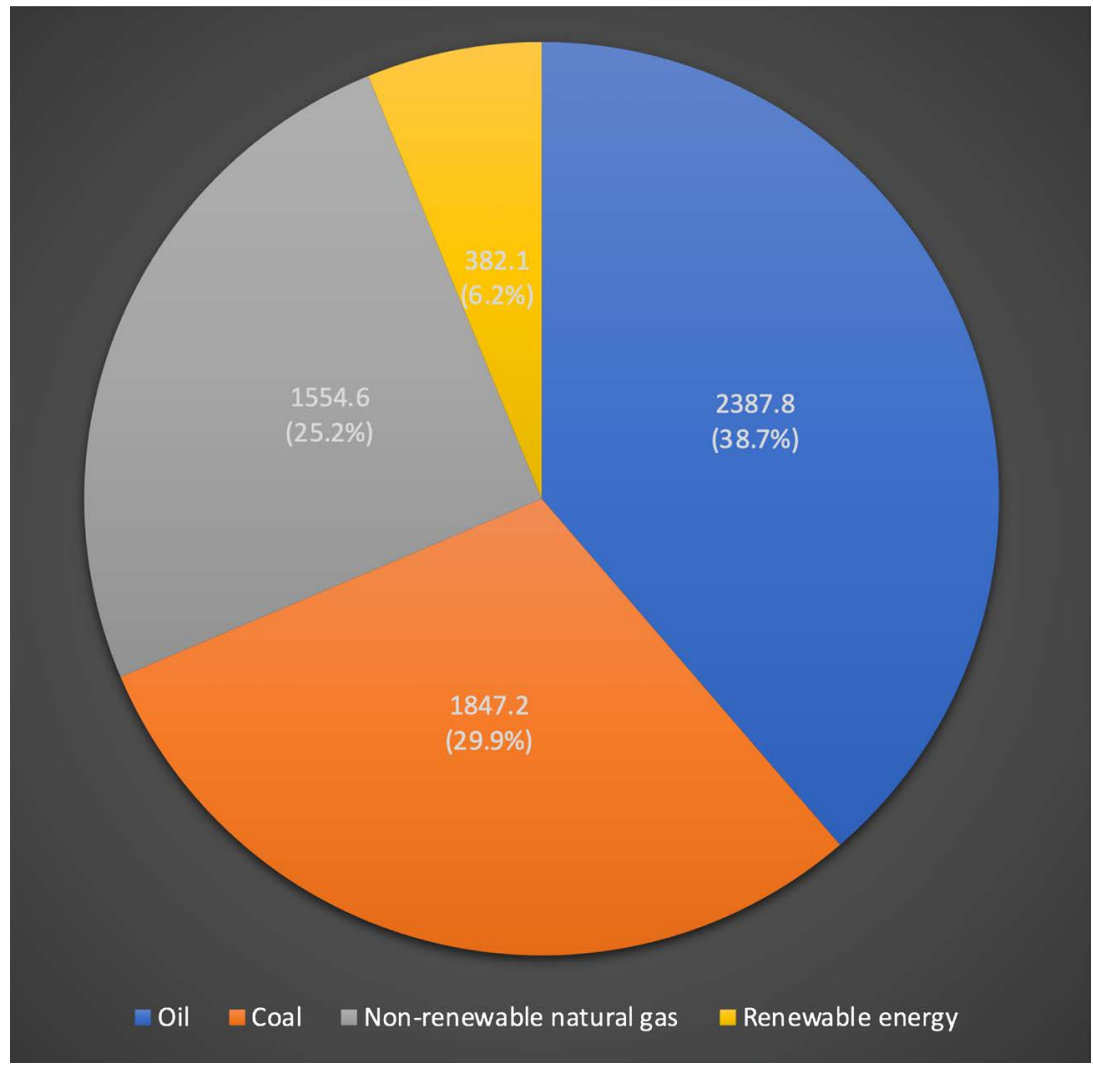

Figure 3. Energy consumption by fuel type in Australia in the year 2017-2018, in petajoules (PJ). Adapted from Australian Department of the Environment and Energy [22].

Table 3. The different states and their implemented policies and future plans for the bio-energy future of Australia.

\begin{tabular}{|c|c|c|c|}
\hline State & Policies implemented \& facilities & Future plans & Reference \\
\hline Queensland & $\begin{array}{l}\text { - } \$ 20 \text { million funding to implement Queensland's } \\
\text { Biofutures plan } \\
\text { - A } 10 \text {-year road map and action plan } \\
\text { - Bunya landfill (1.1 MW) }\end{array}$ & $\begin{array}{l}\text { - Commitment to become Asia-Pacific } \\
\text { hub for biofutures industry } \\
\text { - Vision for a } \$ 1 \text { billion industrial } \\
\text { biotechnology and bioproducts sector } \\
\text { by } 2026\end{array}$ & $\begin{array}{l}\text { Queensland Government } \\
{[23] \text {, }} \\
\text { Clean Energy Council [24] }\end{array}$ \\
\hline $\begin{array}{l}\text { New South } \\
\text { Wales }\end{array}$ & $\begin{array}{l}\text { - EarthPower technologies, Australia's first AD facility } \\
\text { that converts food waste to biogas ( } 3.9 \mathrm{MW} \text { capacity) } \\
\text { - Lucas Heights bioenergy power stations that utilise } \\
\text { landfill } \mathrm{CH}_{4} \text { gas ( } 21.5 \mathrm{MW} \text { capacity) } \\
\text { - } 8 \text { of Sydney Wastewater treatment plants have the } \\
\text { technology to convert } \mathrm{CH}_{4} \text { into electricity } \\
\text { - Moxey Farms Waste-to-Energy Project (3.1 MW) } \\
\text { - Lidcombe Brewery Biogas co-generation }(2.0 \mathrm{MW})\end{array}$ & $\begin{array}{l}\text { - Funding of the Australian Biomass for } \\
\text { Bioenergy Assessment (ABBA) to } \\
\text { stimulate investment into the } \\
\text { renewable energy sector }\end{array}$ & $\begin{array}{l}\text { NSW Government [25], } \\
\text { Clean Energy Council [24] }\end{array}$ \\
\hline Victoria & $\begin{array}{l}\text { - } \$ 700,000 \text { in grant funding via Bioenergy } \\
\text { Infrastructure Fund }\end{array}$ & - The expansion of the bioenergy sector & $\begin{array}{l}\text { Sustainability Victoria [8], } \\
\text { Victoria State Government } \\
{[26]}\end{array}$ \\
\hline South Australia & $\begin{array}{l}\text { - \$ } 150 \text { million Renewable Technology Fund } \\
\text { - Commissioning of Jacobs Group in March } 2015 \text { for } \\
\text { the analysis of bioenergy potential }\end{array}$ & - Bioenergy roadmap for South Australia & $\begin{array}{l}\text { Renewables SA [27], } \\
\text { Government of South } \\
\text { Australia [28] }\end{array}$ \\
\hline
\end{tabular}


expand and develop the bioenergy sector (Table 3). As such, the technological advancements and increase in funding could improve Australia's bioenergy production potential in the coming years.

The Large-Scale Renewable Energy Target set by the Australian Government in the year 2000 aimed to generate 33,000 GWh of renewable energy by 2020 [29]. In 2018, this target was already exceeded; renewable energy contributed $49,339 \mathrm{GWh}$ of electricity [30]. Of this the largest source of renewable energy was hydro $(15,838.8 \mathrm{GWh})$, followed by wind and solar, at 14,989.4 GWh and $9930 \mathrm{GWh}$ respectively [30]. The use of biomass only generated $3534.1 \mathrm{GWh}$ of electricity in 2018 [30]. Hence, bioenergy only contributed 7\% to the total electricity production by renewable sources in 2018.

Currently, bioenergy projects and activity mainly utilise combustion technology to produce electricity instead of anaerobic digestion. Figure 4 shows the Australian renewable energy consumption by fuel type. From this, it can be concluded that biogas accounts only for a very small portion of all the possible renewable fuel types in Australia; $4.2 \%$. The use of biogas makes up only $0.26 \%$ of energy consumption in Australia in 2018. In contrast the combustion of biomass

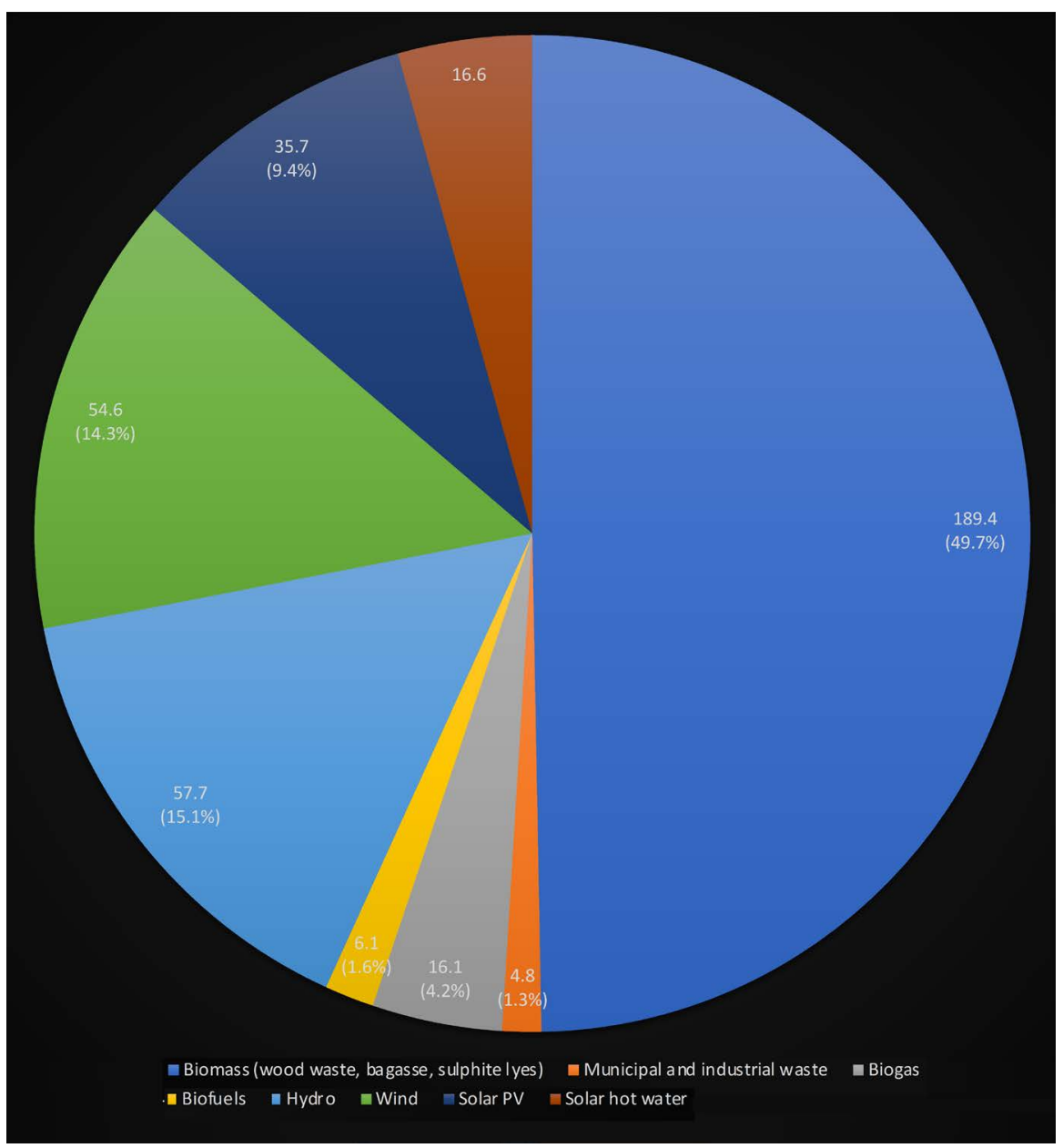

Figure 4. Australian renewable energy consumption by fuel type. Adapted from Australian Department of the Environment and Energy [22]. 
contributed to almost $50 \%$ of the renewable energy consumed in Australia in 2018; 3\% of total energy consumption (Figure 4).

\section{Comparison of International Support for the Biogas Sector}

Australia currently has an estimated total of $242 \mathrm{AD}$ plants with the majority being municipal waste treatment plants and landfill gas treatment plants [31]. Half of the $242 \mathrm{AD}$ plants are landfill gas plants collecting LFG; the LFG is mostly flared instead of being utilised as an energy source due to the poor quality of methane and the lack of infrastructure for purification processes [20]. Twenty AD plants utilise pig manure and about $18 \mathrm{AD}$ plants use wastewater from meat processing and plants as feedstock for biogas production [31]. There are only $5 \mathrm{AD}$ plants that utilise food waste [31], suggesting that the biogas sector requires significant national development.

When compared to other countries, Australia's biogas sector is still in its infancy (Table 4). There is a lack of a national target in terms of biogas production for Australia; France, Sweden, China, Vietnam and Nepal each have their own specific biogas targets (Table 4). In addition, countries like Germany, UK

Table 4. Number of biogas production facilities and key policies implemented to boost biogas sector in Germany, UK, Sweden, France, USA, Nepal, Vietnam, China and Australia.

\begin{tabular}{|c|c|c|c|}
\hline Country & Biogas production facilities & Key policies implemented & Reference \\
\hline Germany & 10,431 Biogas plants & $\begin{array}{l}2002 \text { - Prohibiting the landfilling of waste containing more than } 5 \% \\
\text { organic matter }\end{array}$ & $\begin{array}{l}\text { Carlu, } \\
\text { Truong [20] }\end{array}$ \\
\hline $\begin{array}{l}\text { United } \\
\text { Kingdom }\end{array}$ & 987 Biogas plants in 2016 & Introduction of landfill tax, $\$ A 174.5$ per tonne of active waste & \\
\hline Sweden & $\begin{array}{l}279 \text { Biogas plants in } 2016 \text { with } 47 \text { biomethane } \\
\text { plants suppling biomethane in fuel form }\end{array}$ & Fossil independent transport sector by 2030 & \\
\hline France & $\begin{array}{l}687 \text { Biogas plants in } 2016 \text { and } 47 \text { Biomethane } \\
\text { plant in } 2017\end{array}$ & $\begin{array}{l}\text { - Specific targets set for biogas and biomethane production: } 10 \% \text { of } \\
\text { renewable gas in total energy consumption by } 2030 \\
\text { - Regulation and taxation of landfills }\end{array}$ & \\
\hline United States & $\begin{array}{l}2200 \text { Biogas plants in } 2017 \text {, of which } 70 \% \text { are } \\
\text { anaerobic digestors at wastewater treatment } \\
\text { plants, } 29 \% \text { are landfill gas recovery plants } \\
\text { and } 1 \% \text { are farm-based anaerobic digestors }\end{array}$ & $\begin{array}{l}\text { - } 2016 \text {-Senate Bill } 1383 \text { included a } 40 \% \text { reduction in } \mathrm{CH}_{4} \\
\text { emissions by } 2030 \text {. } \\
\text { - Reduction of landfilling activities by } 50 \% \text { in } 2020 \text { and } 75 \% \text { by } \\
2025\end{array}$ & \\
\hline China & $\begin{array}{l}100,000 \text { Biogas plants and } 43 \text { million } \\
\text { residential-scale digesters in } 2014\end{array}$ & National target of 80 million residential-scale digesters by 2030 & \\
\hline Vietnam & 183,000 Commercial plants & Setting of national diffusion targets & \\
\hline Nepal & 300,000 Domestic biogas units & Setting of national diffusion targets & \\
\hline Australia & $\begin{array}{l}242 \text { Biogas plants, } 50 \% \text { are LFG collection } \\
\text { plants in which } 50 \% \text { of the gas was flared and } \\
\text { not utilised as an energy source }\end{array}$ & $\begin{array}{l}\text { - Large-Scale Renewable Energy Target, an aim to generate } 33,000 \\
\text { GWh of electricity from renewable sources by } 2020 \\
\text { - Emission Reduction Fund to incentivise GHG emission reducing } \\
\text { practices and technologies } \\
\text { - Funding opportunities from the Australian Renewable Energy } \\
\text { Agency (ARENA) for renewable energy projects }\end{array}$ & {$[29]$} \\
\hline
\end{tabular}


and USA have strict regulations regarding landfilling activities to promote the growth of the biogas sector; such supporting policies are still not in place in Australia (Table 4).

\section{Cost Analysis}

When comparing the initial capital costs between wind farms, solar farms and anaerobic digestion facilities, it becomes clear that anaerobic digestion facilities incur a higher cost per MW of capacity. Table 5 provides a comparison in the initial capital cost (ICC) and maximum generating capacity (MGC) of a wind farm, solar farm and a biogas generating facility; the comparison was drawn from projects with similar initial capital costs. Besides, Table 5 also compares the cost of providing $1 \mathrm{MWh}$ of electricity using wind energy, solar energy and biogas generated energy

From Table 5, it can be concluded that anaerobic digestion technology requires a higher initial capital cost per MW of maximum generating capacity; up to 27 million AUD could be required to achieve a $1 \mathrm{MW}$ maximum generating capacity. When compared to solar and wind technologies, where an ICC of 29 million AUD and 26.5 million AUD can build facilities with maximum generating capacities of $25 \mathrm{MW}$ and 12.6 MW respectively (Table 5). Furthermore, the cost to provide $1 \mathrm{MWh}$ of electricity is cheapest with solar power, followed by wind power. Anaerobic digestion technology incurs the highest cost to provide 1 MWh of electricity (Table 5).

Profit margin analysis was conducted to reveal the annual revenue, profit and possible payback period for each of the project listed. The formula to calculate annual electricity output for each project is given as follow:

Table 5. Initial capital cost and maximum generating capacity of renewable projects in Australia and the cost to provide $1 \mathrm{MWh}$ of electricity by fuel type.

\begin{tabular}{|c|c|c|c|c|c|c|}
\hline Project name & State & Technology & MGC (MW) & ICC (\$Amil) & Cost $(\$ \mathrm{~A}) / \mathrm{MWh}$ & Reference \\
\hline \multirow{3}{*}{$\begin{array}{c}\text { Rewaste Plant } \\
\text { at Yarra Valley } \\
\text { Water }\end{array}$} & VIC & $\mathrm{AD}$ & 1 & 27 & $56-267$ & \multirow{3}{*}{$\begin{array}{c}\text { Carlu, Truong } \\
\text { [20], Thi, Lin [32] }\end{array}$} \\
\hline & $\begin{array}{l}\text { Annual total output } \\
\text { (MW) }\end{array}$ & $\begin{array}{l}\text { Annual production } \\
\text { cost (AUD) }\end{array}$ & $\begin{array}{c}\text { Annual revenue } \\
\text { (AUD) }\end{array}$ & $\begin{array}{c}\text { Annual profit/loss } \\
\text { (AUD) }\end{array}$ & $\begin{array}{l}\text { Payback period } \\
\quad \text { (years) }\end{array}$ & \\
\hline & 7425 & 415,800 to $1,982,475$ & 623,700 & $207,900 / 1,358,775$ & 130 & \\
\hline \multirow{3}{*}{$\begin{array}{l}\text { Molong Solar } \\
\text { Farm }\end{array}$} & NSW & Solar & 25 & 29 & $44.50-61.50$ & \multirow{3}{*}{$\begin{array}{l}\text { Clean Energy } \\
\text { Council [33], } \\
\text { ARENA [34] }\end{array}$} \\
\hline & $\begin{array}{l}\text { Annual total output } \\
\text { (MW) }\end{array}$ & $\begin{array}{l}\text { Annual production } \\
\text { cost (AUD) }\end{array}$ & $\begin{array}{c}\text { Annual revenue } \\
\text { (AUD) }\end{array}$ & $\begin{array}{c}\text { Annual profit/loss } \\
\text { (AUD) }\end{array}$ & $\begin{array}{l}\text { Payback period } \\
\quad \text { (years) }\end{array}$ & \\
\hline & 45,864 & $\begin{array}{c}2,040,948 \text { to } \\
2,820,636\end{array}$ & $3,626,256$ & $\begin{array}{l}1,582,308 \text { to } \\
805,620 / \mathrm{NIL}\end{array}$ & 18 to 35 & \\
\hline \multirow{3}{*}{$\begin{array}{l}\text { Ferguson Wind } \\
\text { Farm }\end{array}$} & VIC & Wind & 12.6 & 26.5 & $50-65$ & \multirow{3}{*}{$\begin{array}{l}\text { Clean Energy } \\
\text { Council [33], } \\
\text { ARENA [35] }\end{array}$} \\
\hline & $\begin{array}{c}\text { Annual total output } \\
\text { (MW) }\end{array}$ & $\begin{array}{l}\text { Annual production } \\
\text { cost (AUD) }\end{array}$ & $\begin{array}{c}\text { Annual revenue } \\
\text { (AUD) }\end{array}$ & $\begin{array}{c}\text { Annual profit/loss } \\
\text { (AUD) }\end{array}$ & $\begin{array}{l}\text { Payback period } \\
\text { (years) }\end{array}$ & \\
\hline & 44,029 & $\begin{array}{c}2,201,450 \text { to } \\
2,861,885\end{array}$ & $3,698,436$ & $\begin{array}{l}1,496,986 \text { to } \\
836,551 / \mathrm{NIL}\end{array}$ & 18 to 32 & \\
\hline
\end{tabular}




$$
\mathrm{MW} \times \mathrm{C} \times 365 \text { days } \times 24 \text { hours }=\mathrm{T} \text { MWh }
$$

where $\mathrm{MW}$ is the maximum generating capacity, $\mathrm{C}$ is the capacity factor and $\mathrm{T}$ is the annual total output of electricity. The capacity factor is the ratio of actual generation output to the maximum output over a year. Wind and solar technology are both environmentally dependent and hence, have much smaller capacity factors compared to anaerobic digestion. Wind technology has a capacity factor of between 0.2 to 0.4 (20\% to $40 \%$ ) while large scale solar farms have a capacity factor of around $0.21(21 \%)$. In contrast, anaerobic digestion technology has a capacity factor of between 0.6 to 0.85 (60\% to $85 \%$ ). For ease of comparison, only the highest capacity factors will be used.

The total annual revenue was calculated by multiplying the annual total output by the spot price for electricity/MWh. The spot price for electricity in NSW and VIC are $\$ A 79 / \mathrm{MWh}$ and $\$ \mathrm{~A} 84 / \mathrm{MWh}$. The annual cost can be calculated by multiplying the annual total output by the cost to produce $1 \mathrm{MWh}$ (Table 5).

From the 3 projects with similar initial capital costs, the project utilising AD appeared to be the least profitable with an extremely long payback period compared to the projects utilising solar or wind technology.

In order for $\mathrm{AD}$ plants to achieve financial viability, supporting policies and schemes from the government are required, such as the Emission Reduction Fund (Table 4). The biggest challenge faced by the Australian biogas sector is the lack of industry experience which has translated into high capital costs and small generating capacity [20]. This is especially true when it comes to estimating capital cost and sizing of the generator's capacity during its construction; the lack of reliable data and guidelines may potentially result in extremely high financial risks for biogas project development and operation [20].

\section{Financial Viability Case Studies}

To better illustrate the various factors contributing to the financial viability of a biogas project, a comparison will be made between 3 different completed biogas projects in Australia. These projects will be cross analysed in terms of funding, feedstock, fate of digestate, power purchase agreement and government incentives eligibility. Given the status of industry experience for AD technology in Australia, the capacity factor and operation and maintenance cost will not be factored into this comparison.

The Goulburn Bioenergy plant is the most financially viable amongst the 3 biogas projects. Firstly, approximately $33 \%$ of the project's capital cost was funded by ARENA; it has the lowest capital cost (Table 6). This was higher than the Jankadot Bioenergy plant which had $16 \%$ of its capital cost funded by Clean Technology Investment program and Western Australia State Government (Table 6). The Rewaste plant did not receive government funding, it was also the most expensive project in terms of capital cost. Secondly, the Goulburn Bioenergy plant gets its feedstock directly from the Southern Meats abattoir (Table 6). The plant is situated next to the abattoir to treat its industrial wastewater. This eliminates any 
Table 6. Comparison between capital investments, feedstock cost, disposal cost and government incentives for 3 different biogas projects in Australia.

\begin{tabular}{|c|c|c|c|c|c|c|}
\hline Project Name & Funding & Feedstock & Fate of digestate & $\begin{array}{l}\text { Government } \\
\text { incentives eligibility }\end{array}$ & $\begin{array}{l}\text { Power purchase } \\
\text { agreement (PPA) }\end{array}$ & Reference \\
\hline $\begin{array}{l}\text { Jankadot } \\
\text { Bioenergy plant }\end{array}$ & $\begin{array}{l}\text { - } \$ \text { A } 8 \text { - } 10 \text { million capital } \\
\text { cost out of which: } \\
\text { - } \$ \text { A } 2.2 \text { million loan from } \\
\text { CEFC } \\
\text { - \$A } 1.6 \text { million grant from } \\
\text { Clean Technology } \\
\text { Investment program and } \\
\text { Western Australia State } \\
\text { Government }\end{array}$ & $\begin{array}{l}\text { Commercial and } \\
\text { industrial biowaste } \\
\text { from various } \\
\text { sources }\end{array}$ & $\begin{array}{l}\text { Blended with } \\
\text { existing products } \\
\text { to improve } \\
\text { agricultural values; } \\
\text { sold as } \\
\text { bio-fertiliser }\end{array}$ & NIL & NIL & $\begin{array}{l}\text { Carlu, } \\
\text { Truong } \\
{[20]}\end{array}$ \\
\hline $\begin{array}{l}\text { Rewaste plant at } \\
\text { Yarra Valley } \\
\text { Water }\end{array}$ & $\begin{array}{l}\text { - } \$ \text { A } 27 \text { million capital cost } \\
\text { with no financial support }\end{array}$ & $\begin{array}{l}\text { Commercial and } \\
\text { industrial biowaste } \\
\text { from various } \\
\text { sources }\end{array}$ & $\begin{array}{l}\text { Can be sold for } \\
\text { agricultural use }\end{array}$ & $\begin{array}{l}\text { Emission Reduction } \\
\text { Fund }\end{array}$ & NIL & $\begin{array}{l}\text { Carlu, } \\
\text { Truong } \\
{[20]}\end{array}$ \\
\hline $\begin{array}{l}\text { Goulburn } \\
\text { Bioenergy Project }\end{array}$ & $\begin{array}{l}\text { - \$A } 6.39 \text { million capital cost } \\
\text { out of which: } \\
\text { - \$A } 2.1 \text { million funded by } \\
\text { ARENA }\end{array}$ & $\begin{array}{l}\text { On-site feedstock } \\
\text { supply, industrial } \\
\text { wastewater from } \\
\text { proximal abattoir }\end{array}$ & NIL & $\begin{array}{l}\text { Australian Carbon } \\
\text { Credit Units } \\
\text { (ACCUs) }\end{array}$ & $\begin{array}{l}20 \text { years PPA with } \\
\text { Southern Meats } \\
\text { abattoir }\end{array}$ & $\begin{array}{l}\text { ARENA } \\
{[36]}\end{array}$ \\
\hline
\end{tabular}

cost involved in the purchase and transportation of feedstock. Unlike the Goulburn Bioenergy plant, the Jankadot Bioenergy plant and the Rewaste plant have to obtain their feedstock from suppliers, resulting in higher Levelised Cost Of Electricity (LCOE) (Table 6). Thirdly, the Goulburn Bioenergy plant has a 20 years power purchase agreement with Southern Meats abattoir; the plant operates independently from the abattoir, but the electricity produced will be purchased (Table 6). This helps to strengthen the long-term financial viability of the project. Presently, there are no power purchase agreements for the other 2 plants; the lack of PPAs can translate into a lack of reliable income and may contribute to long term financial constraints (Table 6).

\section{Annual GHG Emission of Australia}

In March 2020, Australia's annual GHG emission was estimated to be $528.7 \mathrm{Mt}$ $\mathrm{CO}_{2}$-e [37]. Table 7 shows the annual emissions by the different sectors, their percentage contributions and a synopsis of how GHG is produced and emitted.

Based on Table 7, the combustion of fuel to generate electricity contributed the most to the annual GHG emission of Australia, up to $172.9 \mathrm{Mt} \mathrm{CO}_{2}-\mathrm{e}$ in the year 2020. Other sectors dependent on the combustion of fuel for energy also contributed significantly to the annual GHG emission; transport sector with 99.7 $\mathrm{Mt} \mathrm{CO}_{2}$-e and stationary energy sector with $102.7 \mathrm{Mt} \mathrm{CO}_{2}$-e (Table 7). The agriculture sector contributed $68 \mathrm{Mt} \mathrm{CO}_{2}$-e and the waste sector contributed 13.1 $\mathrm{Mt} \mathrm{CO}_{2}$-e.

\section{Potential GHG Savings from Biogas Sector}

Australia ratified the Paris Agreement to reduce net GHG emissions by $26 \%$ - 
Table 7. Annual emissions by the different sectors, their percentage contributions in the year 2020; and a synopsis.

\begin{tabular}{|c|c|c|c|c|}
\hline Sector & $\begin{array}{l}\text { Annual emission } \\
\left(\mathrm{Mt} \mathrm{CO}_{2}-\mathrm{e}\right)\end{array}$ & $\begin{array}{l}\text { Percentage } \\
\text { contribution (\%) }\end{array}$ & Synopsis & Reference \\
\hline Energy - electricity & 172.9 & 32.7 & Fuel combustion to generate electricity & Australian \\
\hline Waste & 13.1 & 2.5 & $\begin{array}{l}\text { Emissions from the decomposition, treatment and } \\
\text { combustion of waste }\end{array}$ & $\begin{array}{l}\text { Government } \\
\text { [37], } \\
\text { Hanna [38] }\end{array}$ \\
\hline Energy - transport & 99.7 & 18.9 & $\begin{array}{l}\text { Fuel combustion for vehicles, domestic shipping and } \\
\text { aviation, trains }\end{array}$ & \\
\hline Energy - fugitive emissions & 55.8 & 10.6 & $\begin{array}{l}\text { Fugitive emissions from the extraction, processing and } \\
\text { supplying of coal, natural gas and oil }\end{array}$ & \\
\hline $\begin{array}{l}\text { Energy - stationary energy } \\
\text { excluding electricity }\end{array}$ & 102.7 & 19.4 & $\begin{array}{l}\text { Direct fuel combustion used in energy, mining, } \\
\text { manufacturing, building, primary industries }\end{array}$ & \\
\hline $\begin{array}{l}\text { Industrial processes and } \\
\text { product use }\end{array}$ & 34.6 & 6.5 & $\begin{array}{l}\text { Metal production, chemical industry, synthetic gas } \\
\text { production }\end{array}$ & \\
\hline Agriculture & 68 & 12.9 & $\begin{array}{l}\text { Livestock production, use of fertilisers and soil additives, } \\
\text { residue burning }\end{array}$ & \\
\hline $\begin{array}{l}\text { Land Use, Land Use Change } \\
\text { and Forestry }\end{array}$ & -18.1 & -3.4 & $\begin{array}{l}\text { Deforestation, Reforestation, revegetation, management of } \\
\text { crop, forest and pastures }\end{array}$ & \\
\hline
\end{tabular}

$28 \%$ below the 2005 levels by 2030 ; as estimated $157 \mathrm{Mt} \mathrm{CO}_{2}$-e reduction by the year 2030 [39]. Australia has also committed to a net-zero emission as set by the Paris Agreement by the second half of this century. Moreover, NSW and leading businesses such as AGL, Amcor, Westfarmers and Telstra are committed to a net-zero emissions economy by 2050 [39]. In order to achieve this, the potential GHG savings through the biogas sector cannot be ignored. As aforementioned, the use of AD to treat organic waste results in no net carbon emissions [19].

The direct way to reduce GHG emissions using AD technology is to replace existing methods of waste treatment that are generating GHG emissions. Currently, landfills are major contributors to the GHG emissions from the waste sector. Other sources of GHG emissions that can be directly replaced by $\mathrm{AD}$ technology include the incineration of waste, as well as the treatment of animal manure via anaerobic lagoons. Presently, industrial and agricultural AD plants mostly employ anaerobic lagoons to facilitate $\mathrm{AD}$ which, can generate up to $118 \mathrm{~kg} \mathrm{CO}_{2}$-e per tonne of waste [31] (Table 8). However, anaerobic lagoons are typically used as a pre-treatment for organic waste treatment processes; anaerobic lagoons allow for the separation of sludge from liquid and generally not optimised for $\mathrm{AD}$, functioning mainly as holding tanks; organic stabilisation can take an extremely long period of time and there is potential build-up of inhibitors within the lagoons. Hence, the diversion of organic waste away from these 3 methods of waste treatment and to biogas plants would generate GHG savings.

The indirect way to reduce GHG emissions would be to utilise biogas synthesised from AD plants to generate electricity instead of fuel combustion. While the current status of $\mathrm{AD}$ technology in Australia might not allow for biogas 
Table 8. GHG emission and savings per tonne of waste treated by the various methods.

\begin{tabular}{cccc}
\hline $\begin{array}{c}\text { Waste treatment } \\
\text { method }\end{array}$ & $\begin{array}{c}\text { GHG emission/ } \\
\text { tonne of waste }\end{array}$ & $\begin{array}{c}\text { GHG savings/ } \\
\text { tonne of waste }\end{array}$ & Reference \\
\hline Anaerobic digestion & $\mathrm{NIL}$ & 0.143 tonne of $\mathrm{CO}_{2}$-e & Carlu, Truong [20] \\
Anaerobic lagoons & $118 \mathrm{~kg} \mathrm{CO}_{2}-\mathrm{e}$ & & Phong [18] \\
Landfill & $350 \mathrm{~kg} \mathrm{CO}-\mathrm{e}$ & & Sustainability Victoria [8] \\
Incineration & $1396.5 \mathrm{~kg} \mathrm{CO}_{2}-\mathrm{e}$ & $\mathrm{NIL}$ & Kristanto and Koven [12] \\
Composting & $171.52 \mathrm{~kg} \mathrm{CO}_{2}-\mathrm{e}$ & & Kristanto and Koven [12] \\
\hline
\end{tabular}

to substantially replace coal, crude oil and natural gas to generate electricity, the use of biogas where possible would contribute to GHG savings. The use of biofuel such as methane for transportation can further contribute to GHG savings. However, given the status of the biogas sector in Australia, the use of biofuel would require an accelerated level of research and development.

Table 8 illustrates the GHG savings from utilising AD technology to treat 1 tonne of organic waste as opposed to other waste disposal methods. In 2017, Pickin, Randell [1] reported 6.7 Mt of organic waste going into landfills in Australia. As a result, it can be concluded that around 2,345 $\mathrm{Mt}$ of $\mathrm{CO}_{2}$-e was produced using the value of GHG emission/tonne of waste given in Table 8. In addition, 7.3 Mt of organic waste was recycled via composting; this has the potential to generate approximately $1.25 \mathrm{Mt}$ of $\mathrm{CO}_{2}-\mathrm{e}$. If the same amount of organic waste was diverted away from landfill and composting into biogas, it would have produced $2.02 \mathrm{Mt}$ of $\mathrm{CO}_{2}$-e in GHG savings. Additionally, the anaerobic digestion of $14 \mathrm{Mt}$ of organic waste has the potential to generate approximately $3388 \mathrm{GWh}$ of electricity; this can power an estimated 320 million houses [40]. The diversion of organic waste away from landfill and composting could have potentially increased the electricity generated using biogas in Australia in 2017 and produced GHG savings.

The use of biogas from $\mathrm{AD}$ technology to generate electricity produces the least GHG emission per MWh; 0.251 tonne per MWh [41]. This is significantly lower than that of black coal and brown coal; 0.88 tonne per MWh and 1.22 tonne per MWh respectively [42]. The use of crude oil to generate electricity produces approximately 3 times the amount of GHG emission as the use of biogas, 0.78 tonne per MWh [42]. Lastly, the use of natural gas produces about twice as much GHG emissions as biogas, 0.53 tonne per MWh [42]. As such, the use of biogas to generate electricity is the most desirable in terms of GHG emissions.

In 2017, Germany generated a total of 32,500 GWh of electricity using biogas from the anaerobic digestion of organic waste [43]. This ultimately translated into $27 \mathrm{Mt}$ of $\mathrm{CO}_{2}$-e in GHG savings [43]. In contrast, Australia in 2017 only generated $4472 \mathrm{GWh}$ of electricity using biogas [22]. Since data for GHG savings from biogas usage is not available for 2017 in Australia, value from Germany was used to estimate GHG savings in Australia. Electricity generation of 4472 
GWh by biogas translates into only 3.7 $\mathrm{Mt}$ of $\mathrm{CO}_{2}$-e in GHG savings. The environmental pay off from the use of biogas a fuel source to generate electricity is immense, as illustrated by Germany.

\section{Recommendations and Conclusion}

Given the current status of the biogas sector in Australia, it will be extremely difficult to fully utilise organic waste to generate biogas for energy. The LCOE of using biogas is presently not financially viable due to 2 main factors: the lack of government support and the difficulty in obtaining feedstock. There are two recommendations for new investors to achieve financial viability in the biogas sector. The first would be the construction of biogas plants within the proximity of a feedstock supplier; biogas plants with on-site feedstock will have a lower LCOE by removing the cost of transporting feedstock. Secondly, biogas plants should also strive to obtain long-term PPAs to improve financial viability.

While the use of $\mathrm{AD}$ technology to treat organic waste in Australia may seem ineffective and unprofitable, the potential GHG savings cannot be ignored; anaerobic digestion does not generate GHG emissions and the combustion of biogas to generate electricity produces the least GHG/MWh. The development of the biogas sector in Australia will contribute to less carbon emissions and propel Australia into a carbon neutral future.

\section{Conflicts of Interest}

The authors declare no conflicts of interest regarding the publication of this paper.

\section{References}

[1] Pickin, J., et al. (2018) National Waste Report 2018. Department of the Environment and Energy of Australian Government, Canberra.

[2] Australian Bureau of Statistics (2020) Agricultural Commodities, Australia, 2018-19. Australian Bureau of Statistics, Canberra.

[3] Australian Bureau of Agricultural and Resource Economics and Sciences (2020) Australian Crop Report. Department of Agriculture, Water and the Environment, Canberra.

[4] Ahmad, B., Yadav, V., Yadav, A., Ur Rahman, M., Yuan, W.Z., Li, Z., et al. (2020) Integrated Biorefinery Approach to Valorize Winery Waste: A Review from Waste to Energy Perspectives. Science of the Total Environment, 719, 137315. https://doi.org/10.1016/j.scitotenv.2020.137315

[5] Wine Australia (2019) National Vintage Report 2019. Adelaide, South Australia, Wine Australia Head Office.

[6] Dastjerdi, B., V. Strezov, R. Kumar, and M. Behnia (2019) An Evaluation of the Potential of Waste to Energy Technologies for Residual Solid Waste in New South Wales, Australia. Renewable and Sustainable Energy Reviews, 115, 109398. https://doi.org/10.1016/j.rser.2019.109398

[7] Lu, H.R., Qu, X. and El Hanandeh, A. (2020) Towards a Better Environment-The Municipal Organic Waste Management in Brisbane: Environmental Life Cycle and 
Cost Perspective. Journal of Cleaner Production, 258, 120756. https://doi.org/10.1016/j.jclepro.2020.120756

[8] Sustainability Victoria (2020) Bioenergy Infrastructure Fund Grants. Victoria State Government, Victoria.

[9] United States Environmental Protection Agency (2020) LFG Energy Project Development Handbook. United States Environmental Protection Agency, Washington DC.

[10] Emission Assurance Reduction Committee (2018) Landfill Gas Method Crediting Period Review Report. Department of Agriculture, Canberra.

[11] Energy Information Administration (2019) Biomass explained Waste-to-energy Municipal Solid Waste. Energy Information Administration, Washington DC.

[12] Kristanto, G.A. and Koven, W. (2019) Estimating Greenhouse Gas Emissions from Municipal Solid Waste Management in Depok, Indonesia. City and Environment Interactions, 4, 100027. https://doi.org/10.1016/j.cacint.2020.100027

[13] Y. El Gnaoui, F. Karouach, M. Bakraoui, M. Barz and H. El Bari (2020) Mesophilic Anaerobic Digestion of Food Waste: Effect of Thermal Pretreatment on Improvement of Anaerobic Digestion Process. Energy Reports, 6, 417-422.

https://doi.org/10.1016/j.egyr.2019.11.096

[14] Surendra, K.C., Devin Takara, Andrew G. Hashimoto and Samir Kumar Khanal (2014) Biogas as a Sustainable Energy Source for Developing Countries: Opportunities and Challenges. Renewable and Sustainable Energy Reviews, 31, 846-859. https://doi.org/10.1016/j.rser.2013.12.015

[15] Zaidi, A.A., Feng RuiZhe, Yue Shi, Sohaib Z. Khan and Kashif Mushtaq (2018) Nanoparticles Augmentation on Biogas Yield from Microalgal Biomass Anaerobic Digestion. International Journal of Hydrogen Energy, 43, 14202-14213. https://doi.org/10.1016/j.ijhydene.2018.05.132

[16] Santos, L.A.D., Rebeca Beltrão Valença, Leandro César Santos da Silva, Sávio Henrique de Barros Holanda, Anderson Felipe Viana da Silva, José Fernando Thomé Jucá, et al. (2020) Methane Generation Potential through Anaerobic Digestion of Fruit Waste. Journal of Cleaner Production, 256, 120389. https://doi.org/10.1016/j.jclepro.2020.120389

[17] Dalpaz, R., Odorico Konrad, Carlos Cândido da Silva Cyrne, Henrique Panis Barzotto, Camila Hasan and Marildo Guerini Filho (2020) Using Biogas for Energy Cogeneration: An Analysis of Electric and Thermal Energy Generation from Agro-Industrial Waste. Sustainable Energy Technologies and Assessments, 40, 100774. https://doi.org/10.1016/j.seta.2020.100774

[18] Phong, N.T. (2012) Greenhouse Gas Emissions from Composting and Anaerobic Digestion Plants. INRES, Institute of Crop Science and Resource Conservation. Bonn, D-53115.

[19] Gebrezgabher, S.A., Miranda P.M. Meuwissen, Bram A.M. Prins and Alfons G.J.M. Oude Lansink (2010) Economic Analysis of Anaerobic Digestion-A Case of Green Power Biogas Plant in The Netherlands. NJAS- Wageningen Journal of Life Sciences, 57, 109-115. https://doi.org/10.1016/j.njas.2009.07.006

[20] Carlu, E., Truong, T. and Kundevski, M. (2019) Biogas Opportunities for Australia. ENEA Consulting, Bioenergy Australia.

[21] Sustainability Victoria (2019) Greenhouse Gases from the Waste Sector and Opportunities for Reduction. Sustainability Victoria, Victoria.

[22] Australian Department of the Environment and Energy (2019) Australian Energy Update 2019, in Australian Energy Statistics. Department of the Environment and 
Energy, Canberra.

[23] Queensland Government (2018) Biofutures, Queensland Biofutures 10-Year Roadmap and Action Plan. Queensland Government, Queensland.

[24] Clean Energy Council (2020) Clean Energy Australia Report 2020. Melbourne.

[25] NSW Government (2020) Bioenergy in NSW. https://energy.nsw.gov.au/renewables/renewable-generation/bioenergy

[26] Victoria State Government (2020) Bioenergy. Victoria State Government, Victoria.

[27] Australian Renewable Energy Agency (2020) Bioenergy Roadmap. Australian Renewable Energy Agency, Canberra.

[28] Government of South Australia (2020) Clean Energy Transition. Government of South Australia, Adelaide.

[29] Australian Government (2020) Renewable Energy Target Scheme. Australian Government, Canberra.

[30] Department of Environment and Energy (2019) Australian Energy Statistics, Table O Australian Electricity Generation, by Fuel Type, Physical Units. https://www.energy.gov.au/sites/default/files/2019 aes table o march 2019.pdf

[31] Alexander, S., Harris, P. and McCabe, B.K. (2019) Biogas in the Suburbs: An Untapped Source of Clean Energy? Journal of Cleaner Production, 215, 1025-1035. https://doi.org/10.1016/j.jclepro.2019.01.118

[32] Thi, N.B.D., Lin, C.-Y. and Kumar, G. (2016) Electricity Generation Comparison of Food Waste-Based Bioenergy with Wind and Solar Powers: A Mini Review. Sustainable Environment Research, 26, 197-202. https://doi.org/10.1016/j.serj.2016.06.001

[33] Clean Energy Council (2020) Project Tracker. https://www.cleanenergycouncil.org.au/resources/project-tracker

[34] Australian Renewable Energy Agency (2020) Large-Scale Solar. Australian Government, Canberra.

[35] Australian Renewable Energy Agency (2020) Wind Energy. Australian Government, Canberra.

[36] Australian Renewable Energy Agency (2020) Goulburn Abattoir Powering Itself Using Bioenergy.

https://arena.gov.au/news/goulburn-abattoir-powering-using-bioenergy/?fbclid=Iw AR0be03SIl3qatWWr ihftOG8Nx0SyFhAe1KFDsBKi5oYt-PaHdqKLKqzqI

[37] Australian Government (2020) Quarterly Update of Australia's National Greenhouse Gas Inventory: March 2020. Australian Government, Canberra.

[38] Hanna, E. (2016) Climate Change-Reducing Australia's Emissions. Parliament of Australia, Canberra.

[39] Office of Environment and Heritage (2016) Achieving Zero-Net emissions by 2050. Office of Environment and Heritage, Sydney.

[40] ReWaste (2020) How Will ReWaste Change My Business? http://www.rewaste.com.au/rewaste-and-your-business/

[41] Paolini, V., Francesco Petracchini, Marco Segreto, Laura Tomassetti, Nour Naja \& Angelo Cecinato (2018) Environmental Impact of Biogas: A Short Review of Current Knowledge. Journal of Environmental Science and Health, Part A, 53, 899-906. https://doi.org/10.1080/10934529.2018.1459076

[42] Vivid Economics (2013) Analysis of Electricity Consumption, Electricity Generation Emissions Intensity and Economy-Wide Emissions. A. C. C. Authority. Can- 
berra ACT 2601.

[43] Fachagentur Nachwachsende Rohstoffe e.V (FNR) (2019) Bioenergy in Germany Facts and Figures 2019. Federal Ministry of Food and Agriculture. 18276 Gülzow-Prüzen, Germany. 